\title{
Non-destructive Testing of Welds in Gas Pipelines Repairs with Phased Array Ultrasonic Technique
}

Radoslav Koňár, Milos Mičian

${ }^{1}$ Deparment of Technological Engineering, Faculty of Mechanical Engineering, Uniersity of Zilina in Žilina. Univerzitná 1, 01026 Žilina. Slovak Republic. E-mail: radoslav.konar@fstroj.uniza.sk, milos.mician@fstroj.uniza.sk

The work deals with non-destructive ultrasonic testing of butt and circumferential fillet welds in the repairing of gas pipelines. The new ultrasonic technique Phased Array was used for testing. The article compared the results of Phased Array ultrasonic inspection to X-ray inspection. Experimental samples were taken from real gas pipelines` repairs. It is a circumferential butt joint connecting 2 gas pipelines and 2 other types of circumferential fillet welds occurring during repairs of gas pipelines with pressure steel and steel patch. Experimental testing was conducted on ultrasonic flaw detector OmniScan MX2 by Olympus. Indications of defects in the weld joints obtained by ultrasonic testing are corresponding with the experimental results of X-ray inspection. Experimental results provided information for proposal of manufacture of artificial defects in these samples.

Keywords: Phased Array, repairs of gas pipelines, ultrasonic weld testing

\section{Acknowledgments}

This work has been supported by Scientific Grant Agency of Ministry of Education of the Slovak republic, grant VEGA: 1/0547/11, KEGA: 039ZU-4/2011, and non-profit organization EkoFond project No. 561/PG04/2011.

\section{References}

[1] LANGENBERG, K., J. ; MARKLEIN, R., MAYER, K. (2012). Ultrasonic nondestructive testing of materials - Theoretical foundations. pp. 772. CRC Press, New York.

[2] OLYMPUS (2013). Phased Array Tutorial. Online: 〈http://www.olympus-ims.com/cs/ndt-tutorials/phased-array>.

[3] ANDROŠOVA, Z., SKRBEK, B. (2012). The use of magnetic and ultrasonic structuroscopy for inspection of ADI/AGI castings. In: Manufacturing technology, pp. 93 - 97. J.E. Purkyne University, Ústi nad Labem.

[4] ECLIPSE (2013). Modelling and Inspection Design for NDT. Online: <http://www.eclipsescientific.com/Software/Brochures/ESBeamTool.pdf>.

[5] VRBA, A. (2012). Distribution pipelines - operation and reconstructions. In: Safety of technical equipment 2012. Conference proceedings. pp. 49-55. Vyhne (in Slovak)

[6] KOŇÁR, R., MIČIAN, M., HOPKO, A. (2011). Analysis of boundary conditions for the simulation of welding at the repair of gas pipelines with steel sleeve. In: Communications, pp. 36 - 39. EDIS, Žilina.

[7] ECLIPSE (2013). The company Eclipse Scientific. Online: 〈http://www.eclipsescientific.com>.

[8] KOŇÁR, R. MIČIAN, M. (2012). Numerical simulation of residual stresses and distortions in butt weld in simulation programme SYSWELD. In: Communications, pp. 49 - 54. EDIS, Žilina.

[9] MEŠKO, J., et al. (2011). Shape of heat source in simulation program SYSWELD using different types of gases and welding methods. In: Strojírenská technologie, pp. 6 - 11. J.E. Purkyne University, Ústi nad Labem.

[10] NOVÁK, P., MEŠKO, J., ŽMINDÁK, M. (2011). Finite element implementation of multi-pass fillet weld with phase changes. In: Manufacturing technology, pp.79 - 85. J.E. Purkyne University, Ústi nad Labem.

[11] OLYMPUS (2013). The company Olympus NDT. Online: 〈http://www.olympus-ims.com/cs〉.

[12] OLYMPUS (2012). Phased Array Testing Basic Theory for Industrial Applications. pp. 113. MA Olympus, Waltham.

[13] OLYMPUS (2007). Advances in Phased Array Ultrasonic Technology Applications. pp. 491. MA Olympus, Waltham.

[14] OLYMPUS (2004). Introduction to Phased Array Ultrasonic Technology Applications. pp. 351. MA Olympus, Waltham.

Paper number: M201408

Copyright @ 2014. Published by Manufacturing Technology. All rights reserved. 